\title{
FAKTOR-FAKTOR PENYEBAB RENDAHNYA HASIL BELAJAR SEJARAH DI SMA
}

\author{
Dona Maya Sari, Zulfa, Jaenam \\ Email : zulfaeva75@gmail.com, jaenamjae75@gmail.com \\ Program Studi Pendidikan Sejarah STKIP PGRI Sumatera Barat
}

\begin{abstract}
The purpose of this research is to describe the factors causing the Low Learning Outcomes of Historical learning in Students grade X IPS1 at SMA Negeri 12 Padang. The design that researcher used in this research was a qualitative design. The sample of this research is students of X IPS1 and history teachers at SMA Negeri 12 Padang. The researcher used observation, interview, and documentation technique to get primary data and secondary data. The validity data used triangulation theory to test the accuracy of the data. The analysis of data collection techniques, data reduction showed the conclusions. The results of this research is Internal factors that cause student learning outcomes to decline are in terms of intelligence, attitudes, talents and interests of many underachieved and talented students in the learning process, students' interest in history subjects is still lacking. Students' Attitude in the learning process are less comfortable, generally students struggle and do not pay attention to the teacher in the teaching and learning process.
\end{abstract}

Keywords : Factors, Low, History Learning Outcomes

\section{Pendahuluan}

Mendapatkan hasil belajar yang lebih baik lagi, siswa harus benar-benar siap dan mau belajar dengan memperlihatkan segala kemampuan yang dimilikinya. Apabila hal tersebut sudah dipersiapkan dengan sebaik-baiknya maka hasil belajar yang memuaskan akan dicapainya. Hal tersebut akan lebih sempurna apabila ditunjang dengan adanya peran pihak sekolah terutama guru. Menurut Uzer Usman (2010:6-7) guru merupakan jabatan atau profesi yang memerlukan keahlian khusus sebagai guru.Tugas guru profesi meliputi mendidik, mengajar, dan melatih.Tugas guru dalam bidang kemanusiaan disekolah harus dapat menjadikan dirinya sebagai orang tua kedua. Menurut Slameto (2010:2) belajar adalah suatu proses usaha yang dilakukan seseorang untuk memperoleh suatu perubahan tingkah laku yang baru secara keseluruhan, sebagai hasil pengalamannya sendiri interaksi dalam lingkungan. Menurut Oemar Hamalik (2011:30) hasil belajar adalah tingkah laku yang timbul dari yang tidak tahu menjadi tahu, timbulnya pengertian baru, perubahan dalam sikap dan keterampilan dari pertumbuhan 
jasmani.Hasil belajar dapat disebabkan oleh faktor-faktor yang berasal dari siswa itu sendiri dan guru.Faktorfaktor tersebut sangat memberi pengaruh terhadap hasil belajar siswa yang positif apabila sesuai dengan fungsinya masing-masing.Berdasarkan pengamatan awal penulis di SMA Negeri I2 Padang, observasi penulis menunjukkan bahwa masing-masing permasalahan tersebut tidak berjalan sesuai dengan fungsinya masing-masing.Ini ditandai dari keadaan siswa yang mana sebagian besar siswa masih malas untuk belajar, sering keluar masuk kelas dan tidak membuat tugas.

Hal ini menyebabkan tujuan pembelajaran tidak tercapai seperti yang direncanakan. Hasil pengamatan menunjukkan bahwa hasil belajar sejarah kelas X IPS1 masih rendah atau belum mencapai target Kriteria Ketuntasan Minimum (KKM). Yang mana KKM untuk bidang studi sejarah kelas X adalah sebesar 76. Hal ini terlihat dari 33 siswa kelas X IPS1 yang mengikuti ujian mid semester pada mata pelajaran sejarah hanya 5 orang yang mencapai kriteria ketuntasan minimum, nilainya pun tidak memuaskan dan hanya memenuhi syarat untuk dikatakan lulus saja. Nilai rata-rata siswa pada ujian mid semester sejarah dikelas X IPS1 hanya sebesar 60,00. Sedangkan sebanyak 28 orang siswa dinyatakan belum tuntas. Hal ini sangat jauh berbeda dengan nilai siswa pada kelas X IPS5, dengan nilai rata-rata 78,00 yang mana dari 30 jumlah siswa hanya 9 orang saja yang nilai nya tidak tuntas, sedangkan 21 siswa yang lain dinyatakan tuntas. Maka dapat dilihat pada tabel nilai rata-rata pada hasil belajar sejarah X IPS1, XIPS2, X IPS3 , X IPS4 dan X IPS5 pada tahun 2017/2018. Tetapi yang menjadi fokus penelitian adalah kelas X IPS1 . Dengan demikian nilai ratarata yang terendah adalah dikelas X IPS1 .Berdasarkan tabel diatas dapat disimpulkan bahwa masih rendahnya hasil belajar sejarah siswa yang dibuktikan dengan rendahnya nilai rata-rata di bandingkan dengan kriteria ketuntasan minimum (KKM) yaitu sebesar 76. Kelas X IPS1 dengan jumlah 33 siswa memperoleh nilai rata-rata 60,00. kelas X IPS2 dengan jumlah 35 siswa memperoleh nilai rata-rata 74,60. X IPS3 dengan jumlah 35 siswa memperoleh nilai rata-rata 73,90. Kelas X IPS4 dengan jumlah 35 siswa memperoleh nilai rata-rata 75,60. Kelas X IPS5 dengan jumlah 30 siswa memperoleh nilai ratarata 78,00. dari kelas X IPS1, X IPS2, X IPS3 , X IPS4 dan X IPS5, ada beberapa siswa yang tidak mencapai KKM yang telah ditentukan hal ini dapat disebabkan karena adanya gangguan atau kesulitan belajar yang dialami oleh siswa pada saat menganalisis pengertian sejarah menurut para ahli. Berdasarkan pemaparan diatas terlihat bahwa sebagian ada $85 \%$ siswa kelas X IPS1 pada mata pelajaran sejarah masih banyak yang belum tuntas karena nilai mereka belum 
mencapai kriteria ketuntasan minimun dan $15 \%$ saja siswa yang tuntas, Untuk itu peneliti ingin melakukan penelitian dengan judul "Faktor-Faktor Penyebab Rendahnya Hasil Belajar Sejarah Pada Siswa Kelas XIPS1 SMA Negeri 12 Padang”. Sesuai dengan batasan masalah diatas maka tujuan penelitian untuk mendeskripsikan : Faktor-faktor penyebab rendahnya hasil belajar siswa kelas X IPSI pada mata pelajaran sejarah di SMA Negeri 12 Padang.

\section{Metode Penelitian}

Berdasarkan masalah yang diteliti, jenis penelitian yang digunakan dalam penelitian ini adalah kualitatif, karena peneliti berusaha mendeskripsikan atau memberikan gambaran mengenai faktor-faktor penyebab rendahnya hasil belajar sejarah pada siswa kelas X IPS1 di SMA Negeri 12 Padang dalam pembelajaran sejarah. Hal ini sesuai dengan pendapat Bogdan dan Tylor dalam Maleong (2009:84) yang menyatakan bahwa studi evaluasi dengan analisis kualitatif merupakan proses yang menghasilkan data deskriptif berupa kata-kata tertulis dari orang-orang atau perilaku yang diamati. Penelitian ini dilaksanakan di SMA Negeri 12 Padang pada semester genap tahun pelajaran 2017/2018. Dalam upaya untuk penelitian, peneliti juga melakukan wawancara dengan wakil di SMA Negeri 12 Padang. Sesuai dengan sumber data yang digunakan, maka teknik pengumpulan data pada penelitian ini adalah observasi,wawancara, dan studi dokumentasi.

\section{Hasil dan Pembahasan}

Hasil penelitian ditunjukan untuk mengetahui faktor-faktor penyebab rendahnya hasil belajar sejarah pada kelas X IPS1 SMA Negeri 12 Padang data dari informan penelitian ini menggunakan teknik observasi, wawancara, dan dokumentasi.Setelah data terkumpul, dianalisis, diseleksi, ditelaah dan direduksi dengan demikian kesimpulannya dapat diverifikasi untuk di jadikan temuan penelitian terhadap masalah yang diteliti. Data yang dideskripsikan pada bagian ini adalah hasil observasi dan wawancara yang peneliti lakukan terhadap peserta didik kelas $\mathrm{X}$ IPS1 yang berkaitan dengan hasil belajar sejarah pada kelas X IPS1 SMA Negeri 12 Padang. Peneliti melakukan penelitian ini pada semester Genap 2017/2018. Data pendukung yang peneliti gunakan adalah dengan melakukan wawancara bersama peserta didik kelas X IPS1, guru mata pelajaran sejarah yang mengajar di kelas X IPS1 dan wakil kurikulum SMA Negeri 12 Padang. Berdasarkan penelitian dan data yang ditemukan pada tahun ajaran 2017/2018, maka peneliti 
melakukan penelitian di SMA Negeri 12 Padang yang dimulai pada Tgl 5 Januari sampai 27 Januari 2018.Kemudian untuk memperkuat informasi dari siswa dan guru, peneliti melakukan pengamatan langsung pada lokasi penelitian. Dari kegiatan pengamatan dan wawancara maka ditemukan faktor-faktor penyebab rendahnya hasil belajar sejarah pada kelas X IPS1 SMA Negeri 12 Padang sebagai yang di uraikan di bawah ini: Intelegensi atau kecerdasan merupakan daya serap pikir anak yang sangat cepat yang dimiliki seseorang. Siswa yang cerdas akan mudah menangkap apa yang di jelaskan oleh guru sedangkan Siswa yang mempunyai intelegensi yang rendah susah menangkap dengan apa yang dijelaskan oleh guru. Prestasi belajar seseorang akan di tentukan oleh faktor diri (internal), baik secara fisiologis maupun secara psikologis, beserta usaha yang di lakukannya. Di sini terbukti dengan penulis melakukan wawancara di SMA Negeri 12 Padang dengan salah seorang Siswa yang mendapatkan nilai di bawah KKM (Kriteria Ketuntasan Minimal) yaitu 60 sedangkan KKM (Kriteria Ketuntasan Minimal) adalah 76. Sikap merupakan salah satu perilaku yang dimiliki seseorang.Dari sini bisa dilihat bagaimana sikap siswa dalam mengikuti pembelajaran.siswa yang menyukai suatu pembelajaran mereka akan memperhatikan guru dengan baik dan memperhatikan guru dan selalu duduk didepan dan jarang keluar masuk mereka akan betah didalam kelas. Sikap adalah gejala internal yang berdimensi afektif, berupa kecenderungan untuk mereaksi atau merespon dengan cara yang relatif tetap terhadap obyek orang, barang, dan sebagainya, baik secara positif maupun negatif. Bagi peserta didik yang jarang memperhatikan guru dan sering keluar masuk kelas dan duduk duduk diluar, pertanda mereka menunjukan sikap yang membosankan atau tidak baik dalam belajar atau mereka kurang menyukai. Bakat adalah kemampuan potensial yang dimiliki seseorang untuk mencapai keberhasilan pada masa yang akan datang. Prestasi belajar seseorang akan di tentukan oleh faktor diri (internal), baik secara fisiologis maupun secara psikologis, beserta usaha yang dilakukannya. Bakat dalam belajar juga di pengaruhi oleh waktu dan kesempatan. Waktu dan kesempatan yang dimiliki oleh setiap individu berbeda sehingga akan berpengaruh terhadap perbedaan kemampuan siswa. Minat juga menjadi salah satu faktor internal yang mempengaruhi cara belajar Siswa, apabila Siswa tidak berminat dalam mengikuti pembelajaran sejarah akan berdampak pada sikap Siswa yang kurang memperhatikan guru dalam belajar. timbulnya minat karena adanya motif tertentu, motif merupakan penggerak dalam diri seseorang untuk melakukan aktifitas tertentu dan tujuan tertentu, sedangkan motivasi merupakan perubahan energi dalam diri (pribadi) seseorang yang di tandai dengan timbulnya perasaan dan reaksi untuk mencapai tujuan. 
minat yaitu kecenderungan dan kegairahan yang tinggi atau keinginan yang besar terhadap sesuatu. Oleh karena itu, minat dapat mempengaruhi pencapaian hasil belajar dalam mata pelajaran tertentu.Motivasi merupakan salah satu faktor internal yang ada dalam diri peserta didik, karena dari motivasi ini timbul minat dan sikap yang baik terhadap peserta didik dalam mengikuti pembelajaran.Motivasi adalah perubahan enenrgi yang ada dalam diri (pribadi) yang timbul dalam diri seseorang melalui perasaan untuk mencapai tujuan yang di inginkan. Lingkungan keluarga baik langsung maupun tidak langsung akan berpengaruh terhadap pencapaian hasil belajar siswa. Faktor keluarga sangat berpengaruh sekali dengan hasil belajar peserta didik karena waktu anak lebih banyak dengan orang tua, status ekonomi, hubungan orang tua dengan anak, bimbingan orang tua, dan memantau perkembangan anak. Lingkungan sekolah sangat berpengaruh dengan proses belajar siswa. Setelah masuk sekolah siswa harus menyesuaikan aturan-aturan yang berlaku disekolah dan guru juga harus menyesuaikan diri dengan tuntutan sekolah tepat waktu datang sekolah dan memberikan sanksi apabila siswa melanggar peraturan sekolah. Lingkungan masyarakat sangat berpengaruh dengan proses belajar siswa. Setelah masuk sekolah siswa harus menyesuaikan dengan keadaan lingkungan disekitarnya dan masyarakat juga harus menyesuaikan diri dengan tuntutan aturan sekolah serta sekolah memberikan sanksi apabila masyarakat melanggar kesepakatan peraturan dengan pihak sekolah. Siswa yang tidak termotivasi dalam belajar dapat dilihat dari intelegensi dan kurangnya minat siswa dan sikap siswa dalam belajar, siswa yang memiliki bakat dan motivasi pasti mereka mengikuti pembelajaran dengan baik, siswa yang kurang berbakat menunjukan sikap yang tidak baik di dalam belajar dan kurang berminat dalam mengikuti pembelajaran dan akan berdampak pada nilai siswa yang mendapatkan nilai di bawah KKM. Sedangkan motivasi ini di masukan ke dalam dua jenis yaitu motivasi intrisik dan motivasi ektrinsik.Motivasi intrinsik adalah motivasi yang berasal dalam diri siswa yang meliputi hasrat dalam keinginan utuk berhasil dan dorongan dan cita-cita.Dalam hal ini, penghargaan dan hadia tidak di perlukan.Seharusnya orang tua bisa mengajarkan pada siswa dan mengingatkan siswa pada pelajaran karena waktu orang tua lebih banyak dari pada guru disekolah.Orang tua yang kurang mengontrol atau memperhatikan anak.Kebanyakan orang tua siswa hanya sibuk mencari nafkah apalagi ekonomi keluarga rendah anak hanya bisa bertemu dengan orang tua pagi sebelum berangkat sekolah dan malam pulang dari bekerja itupun orang tua sudah letih sehingga tidak waktu untuk menanyakan bagaimana perkembangan anak disekolah.Lingkungan sekolah banyak yang siswa melanggar peraturan yang 
ada disekolah seperti terlambat datang kesekolah, pakaian kurang rapi, dan siswa keluar masuk pada jam pelajaran. Sedangkan dalam proses belajar mengajar masih banyak oknum guru yang acuh terhadap siswa.

\section{Simpulan}

Hasil penelitian ini adalah sebagai berikut: Faktor internal yang menyebabkan hasil belajar siswa menurun adalah dari segi pembelajaran yang kurang menarik dapat menyebabkan kurangnya bakat siswa terhadap pembelajaran sejarah, sehingga bagi siswa yang mempunyai daya serap yang rendah maka akan berdampak kepada nilai-nilai siswa. Faktor eksternal yang paling mempengaruhi hasil belajar adalah keluarga, sekolah dan juga masyarakat.Dari segi keluarga, keluarga sangat penting dalam mendidik anak namun karena tuntutan profesi orang tua kurang memperhatikan dalam mengingat anak belajar dan juga tidak adanya dukungan antara orang tua dengan pihak sekolah.Dari Segi lingkungan sekolah banyak siswa melanggar peraturan yang ada di sekolah seperti terlambat datang ke sekolah, pakaian kurang rapi, dan kurangnya disiplin siswa. Dari segi lingkungan masyarakat kebanyakan siswa keluar masuk pada saat jam istirahat, padahal gerbang sekolah ditutup oleh satpam, tetapi kenapa masih banyaknya siswa yang berkeliaran diluar pekarangan sekolah. Dari ketiga faktor tersebut sangat berpengaruh terhadap siswa, dan yang lebih berpengaruh yaitu dari faktor keluaraga karna keluarga lebih utama untung mendorong siswa dalam mencapai prestasi, dan waktu siswa lebih banyak dirumah diandingkan di sekolah.

\section{DAFTAR PUSTAKA}

Anas Sudijono. 2011. Pengantar Evaluasi Pendidikan. Jakarta : PT Raja Grafindo Persada

Arikunto, Suharsimi. 2010. Prosedur Penelitian Suatu Pendekatan Praktek. Yogyakarta : Rineka Cipta

Dadang Supardan. 2015. Pembelajaran Ilmu Pengetahuan Sosial. Jakarta: PT Bumi Aksara Iskandar.2009. Metodologi Penelitian Pendidikan dan Sosial.Jakarta : GP Pres

Meiliyah Ulfa Muchlis. 2012. Kemampuan Belajar Siswa Melalui Model Pembelajaran Kooperatif Tipe NHT Pada Materi Ikatan Ikatan Sejarah Di Kelas X SMA Lamongan. Jurnal Pendidikan Volume 30, Nomor 01, Hal: 1-12 